\title{
Elżbieta Siarkiewicz, Ewa Trębińska-Szumigraj, Daria Zielińska-Pękał, „Edukacyjne prowokacje. Wykorzystanie etnografii performatywnej $w$ procesie kształcenia doradców", Oficyna Wydawnicza Impuls, Kraków 2012
}

Współczesne szkolnictwo wyższe stoi przed zadaniem wyposażenia absolwentów poszczególnych kierunków w zestawy kompetencji, umożliwiające efektywne funkcjonowanie na niestabilnym rynku pracy, wykonywanie określonych/wymarzonych profesji, a przede wszystkim radzenia sobie (bycie) w ponowoczesnym świecie. Na podstawie obserwacji potocznej można stwierdzić, że aby osiągnąć ten ambitny cel nie wystarczy poprzestać na przekazywaniu studentom wiedzy teoretycznej. W rzeczywistości przesyconej informacją, która szybko się dewaluacje, niezmiernie ważne jest stworzenie uczącym się warunków do konstruowania różnorodnych umiejętności i postaw w oparciu o ich doświadczenia zdobywane również poza edukacją formalną.

Problematyce konstruowania kompetencji młodych dorosłych, w ramach procesu dydaktycznego wzbogaconego elementami edukacji pozaformalnej i nieformalnej poświęcona została książka Elżbiety Siarkiewicz, Ewy Trębińskiej-Szumigraj i Darii Zielińskiej-Pękal pt. „Edukacyjne prowokacje. Wykorzystywanie etnografii performatywnej w procesie kształcenia studentów". Publikacja ta zawiera opis doświadczeń, spostrzeżeń i zaleceń pracowniczek Katedry Pedagogiki Społecznej Uniwersytetu Zielonogórskiego, które prowadzą wykłady, ćwiczenia i seminaria dotyczące diagnozy pedagogicznej, metody pracy doradców, poradnictwa i poradoznawstwa. Autorki recenzowanej pozycji na co dzień pracują z przyszłymi pedagogami, doradcami oraz pracownikami socjalnymi, wykorzystują bogate doświadczenie zawodowe zdobyte w pracy doradczej, terapeutycznej i diagnostycznej, w dzia- 
łalności badawczej i naukowej. Każda z nich wydała już kilka książek oraz opublikowała wiele artykułów dotyczących problematyki poradniczej.

Recenzowana książka składa się z sześciu zasadniczych rozdziałów. Pierwszy z nich poświęcony został zagadnieniu profesjonalizmu, sposobom jego rozumienia i definiowania. Ukazuje ewolucję w kształceniu doradców pod wpływem przejścia od „(...) profesjonalizmu rozumianego tradycyjnie do profesjonalizmu nowego, którego domaga się nieustannie zmieniająca się, dynamiczna i nieprzewidywalną rzeczywistość" (s. 8).

W trzech kolejnych rozdziałach opisane zostały trzy „projekty/prowokacje", które przeprowadziły autorki wraz ze studentami na zielonogórskim rynku w ramach Festiwalu Nauki. Działania te osadzone zostały w schemacie etnografii performatywnej stanowiącej jeden $\mathrm{z}$ wariantów prowadzenia eksploracji podporządkowanych, nacechowanej refleksyjnością strategii badań w działaniu. Co ważne, projekty te nie zostały zaprezentowane chronologicznie, ale według „kryterium merytorycznego” sprzężonego z aspektami, którym podporządkowane zostały ich opisy. Pierwszy projekt nosi tytuł Drzewo wsparcia, jego opis oscylował głównie wokół fazy przygotowawczej - przejścia od idei do jej urzeczywistnienia. Jako drugi ukazany został projekt pt. Etiudy poradnicze, którego opis skoncentrowany był na fazie realizacji, czyli przebiegu „prowokacji”. Stragan dobrych rad to ostatni z przedstawionych projektów, jego opis skupiał się na fazie ewaluacji, polegającej na ocenie i interpretacji uzyskanych rezultatów oraz refleksji, która pojawiła się jako wytwór namysłu nad całym przedsięwzięciem i uczestnictwem w nim. Każdy z tych trzech rozdziałów wieńczy nieduży zbiór scenariuszy przykładowych zajęć ze studentami.

W rozdziale piątym zaprezentowane zostały korzyści wynikające z osadzenia procesu nabywania przez studentów doświadczeń $i$ kompetencji związanych z zawodem doradcy na założeniach konstruktywizmu. Podkreślono w nim złożoność procesu stawania się doradcą, wielkowymiarowość tej profesji, do której nie można przygotować studentów bez stosowania zróżnicowanych metod kształcenia uwrażliwiających uczącego się na Innego.

Ostatni rozdział poświęcony został przybliżeniu czytelnikowi obranej przez badaczki perspektywy metodologicznej oraz uwrażliwienia go na możliwość prowadzenia edukacji akademickiej poza anonimowymi murami uczelni i przeniesienia jej do heterogenicznej przestrzeni publicznej.

Natomiast w zakończeniu książki zawarto wnioski dotyczące wybranych efektów posługiwania się w procesie kształcenia doradców oraz w „procesie konstruowania poradniczej refleksji" (s. 12), nietypowymi metodami i formami dydaktycznych. 
Struktura i układ poszczególnych rozdziałów publikacji dowodzi, że autorki zadbały, aby omawiana $\mathrm{w}$ niej problematyka została ukazana zarówno pod kątem teoretycznym, jak i praktycznym. Jej celem jest zaprezentowanie efektywnych metod uczenia studentów, wskazanie niekonwencjonalnych sposobów kompleksowego przygotowania młodych dorosłych do pracy w charakterze profesjonalnych doradców, czyli „(...) tych, którzy profesjonalnie pomagają innym" (s. 13), zachęcenie nauczycieli akademickich do krytycznej oceny własnych działań dydaktycznych i przeistaczania się z wykładowców koncentrujących się na technologicznym przekazie wiedzy teoretycznej, w refleksyjnych organizatorów gotowych do nadawania rozwojowego i edukacyjnego charakteru elementom świata codziennego $^{1}$, umożliwiających uczenie się, a nawet charakterystyczne dla dydaktyki krytycznej poznawanie specyfiki danej profesji.

W recenzowanej książce, powołując się na stanowisko Bogusławy Gołębniak, dokonano wyraźnego rozróżnienia między zawodowstwem a profesjonalizmem. Zaznaczono, że bycie dobrym doradcą wykracza poza ramy zawodu, czyli zespołu czynności wykonywanych w celach zarobkowych i jest kompilacją: profesji (zbioru działań podejmowanych przez eksperta w danej dziedzinie, czyli osoby posiadającej uwierzytelnione i powszechnie uznawane kompetencje, które nieustająco optymalizuje), pasji (utożsamianej z nacechowanym entuzjazmem intelektualnym i emocjonalnym zaangażowaniem w realizację określonych działań) i powołania (utożsamianego $\mathrm{z}$ wewnętrzną potrzebą podejmowania określonych działań) .

W publikacji zwrócono uwagę, że heterogeniczność współczesnego świata stawia przed profesjonalnym doradcą nowe cele. Obliguje go do rezygnacji z preferowanego przez pracodawców i klientów poradnictwa dyrektywnego, na rzecz realizacji założeń poradnictwa dialogowego i liberalnego oraz gotowości udzielania pomocy konkretnym osobom w konstruowaniu przez nie własnych tożsamości i biografii. Zaznaczono, że sprostanie tym celom wymaga od doradcy nie tylko „(...) utrzymania osobistych standardów etycznych, dyscypliny w wykonaniu czynności zawodowych, aktualizowania wiedzy teoretycznej i praktycznej" (s. 16), ale przede wszystkim refleksyjności, (...) a co za tym idzie - poszukiwania i budowania wiedzy w działaniu" (s. 21).

Powszechnie przyjmuje się, że do realizacji zadań wynikających ze sposobu pojmowania nowoczesnego profesjonalizmu przysposobić mają przy-

1 M. Malewski, Od nauczania do uczenia się. O paradygmatycznej zmianie w andragogice, Wrocław 2010, s. 43. 
szłych doradców uczelnie wyższe. Tymczasem, jak słusznie zauważają autorki recenzowanej książki, prowadzony w nich proces edukacyjny nierzadko podporządkowany jest zbyt ogólnemu programowi kształcenia narzucanemu przez zewnętrzne organy. Przesycony wiedzą teoretyczną, częstokroć przekrojową, gdyż wyselekcjonowaną zgodnie z określonymi poglądami naukowymi danego wykładowcy lub spisem treści podręcznika obowiązującego na zajęciach, oraz sformalizowany i zhierarchizowany, czemu sprzyjają, m.in. tradycyjne formy prowadzenia zajęć, czy oceniania.

Trzy „projekty/prowokacje” przeprowadzone w przestrzeni publicznej przez E. Trębińską-Szumigraj, D. Zielińską-Pękał i E. Siarkiewicz: Drzewo wsparcia, Etiudy poradnicze oraz Stragan dobrych rad są znakomitymi przykładami nietradycyjnych - wręcz alternatywnych - działań dydaktycznych przełamujących akademicką rutynę. Ich erudycyjne opisy prezentują możliwość oparcia procesu edukacyjnego na organizacji np. happeningów ulicznych bazujących na: metaforze, założeniach gier miejskich, czy prezentacji udramatyzowanych etiud. Prezentują metody konstruowania performatywnego doświadczenia sytuacyjnego i umożliwiania studentom wejścia w poradniczą interakcję z Innym -potencjalnym klientem. Obrazują sposoby uczenia się empatii, „wchodzenia” w sytuację osoby szukającej wsparcia i radzenia sobie z jej oczekiwaniami, oswojenia się z poczuciem obcości towarzyszącej niemal każdemu pierwszemu spotkaniu z nowym klientem, czy weryfikacji początkowych planów działania pod wpływem nieprzewianych/ nowych elementów sytuacji doradczej.

Szczególnym atutem opisanych projektów edukacyjnych było osadzenie ich w metodologii badań w działaniu. Autorki książki udowodniły, że immanentne cechy tej procedury badawczej umożliwiają uczeniu się, a także konstruowaniu różnorodnych kompetencji. Procedura ta, opierając się na sprzyjającej dialogowi współpracy, pozwoliła uczestnikom poszczególnych prowokacji na: uczenie się współdziałania, uczenie się siebie i od siebie nawzajem, redefinicję relacji student-student, student-wykładowca. Dzięki uczestniczącemu charakterowi, polegającemu na angażowaniu biorących w niej udział jednostek do testowania ich wiedzy, umiejętności i postaw, umożliwiła ich partycypatorom krytyczną ocenę posiadanych kompetencji zarówno zawodowych, jak i miękkich - oraz konstruowanie nowych. Można nawet stwierdzić, że jej refleksyjny wydźwięk, bazujący na permanentnym przenikaniu się myślenia i działania, dał studentom biorącym udział w projektach możliwość stawanie się doradcami w codzienności.

W recenzowanej książce brak jednak wyraźnego wykazania zasadniczej własności badań w działaniu pozwalającej na monitorowanie postępowania 
badawczego, czyli ich cykliczności/„autorefleksyjnej spiralności”, bazującą na idei koła hermeneutycznego, „(...) w którym jeden cykl, czy też element spirali, jest zaledwie jednym krokiem w poznawaniu"2. Co prawda w opisach poszczególnych projektów zasygnalizowano, które elementy obranej procedury metodologicznej uległy przeformułowywaniu wraz ze zmieniającymi się uwarunkowaniami procesu badawczego i dydaktycznego, ale nie ukazano kolejnych odsłon poszczególnych eksploracji oraz zmian jakie w nich wprowadzono na etapie planowania/konceptualizacji i działania/realizacji pod wpływem kończącej poprzedni „cykl” refleksji. Przez to zaprezentowane w publikacji prowokacje jawią się, jako nienależne byty nadal oczekujące na swoje kontynuację.

Rozpatrując aspekt metodologiczny recenzowanej pozycji można również zadać pytanie: Czy niezbędnym jest odwoływanie się w tej książce do terminu etnografia performatywna? Być może właściwszym byłoby pozostanie przy kontekstualnej kategorii badań w działaniu i posługiwaniem się pojęciami: uczenie się w działaniu, uczenia się poza murami szkoły/uczelni itp.

Reasumując można stwierdzić, że recenzowana książka ma dużą wartość merytoryczną i niezwykle czytelny układ treści. Podobnie jak zaprezentowane w niej projekty edukacyjne wyróżnia się metaforycznością i konceptualnością. I choć w głównej mierze dotyczy procesu kształcenia doradców, to nie sposób odmówić zawartym w niej treściom słuszności wobec wyzwań stojących przed całym współczesnym szkolnictwem wyższym. W błyskotliwy i klarowny sposób ukazuje metody, które umożliwiają uczącym się łączenie dotychczasowych doświadczeń z wiedzą o charakterze naukowym i potocznym, konstruowanie różnorodnych kompetencji oraz redefinicje siebie i swoich działań w świecie społecznym i materialnym. Zaprezentowane w tej publikacji tezy i opisy praktycznych działań pedagogicznych umożliwiają czytelnikowi prowadzenie wielopłaszczyznowych rozważań nad problematyką przygotowywania młodych dorosłych do roli refleksyjnych badaczy i radzenia sobie w trudnych zawodowych sytuacjach.

Kinga Majchrzak

2 T. Bauman, T. Pilch, Zasady badań pedagogicznych. Strategie ilościowe i jakościowe, Warszawa 2001, s. 311. 